\title{
Spore Forming Bacterium from Oil Contaminated Soil as a Source of a Lipase Enzyme with Exogeneous Lipolytic Activity
}

\author{
Magda M. Aly ${ }^{a^{*}}$, Hadeel Abdul-Aziz Al-Shareef ${ }^{\text {a }}$ Huda A. Quri ${ }^{\mathrm{a}}$ and Madeha \\ N. Al-seeni ${ }^{\text {b }}$ \\ ${ }^{a}$ Biological Sciences Department, Faculty of Science, King Abdulaziz University, \\ ${ }^{b}$ Department of Biochemistry, Faculty of Science, King Abdulaziz University, PO. Box 42805, Jeddah 21551, \\ Saudi Arabia, * email: magdammali@ hotmail.com
}

\begin{abstract}
Twenty two bacterial isolates were obtained from oil contaminated soil, collected from some oil stations in Jeddah. All the obtained bacterial isolates were screened on Tween-Yeast extract medium for lipase production. Three bacterial isolates HM10, HM15 and HM20 showed the highest growth and lipase production agar medium, thus they were grown in liquid olive oil medium at $120 \mathrm{rpm}$. Maximum lipase production was obtained by the isolate HM10. The isolate HM10 was characterized and identified through physiological, biochemical tests and culture characteristics in addition to $16 S$ rDNA as Bacillus coagulans. The effects of different factors on the enzyme production were studied. It was found that bacterial growth in medium 4 at initial pH 7.0, containing olive oil and incubation at $37^{\circ} \mathrm{C}$ for 2 days at $120 \mathrm{rpm}$ were the most favorable conditions for maximum lipase production by the tested isolate. The bacterial isolate was grown using the best culture conditions and lipase was precipitated using $80 \%$ of ammonium sulphate, purified using colum chromatography and characterized. The molecular weight was $62 \mathrm{kDa}$ and the maximum enzyme activity was at $50^{\circ} \mathrm{C}$ and $\mathrm{pH}$ 7.0. Presence of $\mathrm{K}^{+}$and $\mathrm{Ca}^{++}$ions enhance enzyme activity.

Keywords: Lipase, Bacillus, Tween, olive oil, Enzyme, production
\end{abstract}

\section{Introduction}

Lipases secreted into the culture medium by different bacteria and fungi and recently have attracted considerable attention owing to their biotechnological potential (kim et al., 2001; Maugard et al., 2002). Bacterial lipases were observed in the strains of Gram negative bacteria Serratia marescens, Pseudomonas aeruginosa (Hasan et al., 2006; Moeller et al., 1992) and the Gram positive bacteria Bacillus, Acinetobacter, Staphylococcus, Streptococcus, Burkholderia, Achromobacter, Arthrobacter, Alcaligenes and Chromobacterium (Ramchuran et al., 2006; Borkar et al., 2009; Sangeetha et al., 2011). Other genera like and Streptomyces (Abramic et al., 1999; Riaz et al., 2010; Sangeetha et al., 2011) have been studied as lipase producer but lipases of this genus were not intensively studied (Jaeger et al., 1994). Some bacterial lipases have been purified and characterized and the responsible genes have been sequenced (Dartois et al., 1992; Cruz et al., 1994, Sommer et al., 1997). Two very homologous lipases from Streptomyces exfoliatus and S. albus have been characterized (Perez et al., 1993; Cruz et al., 1994) and the three-dimensional structure of the S. exfoliatus enzyme has been elucidated (Wei et al., 1998). Further, encoding gene of lipase from Streptomyces cinnamomeus was cloned and sequenced and no similarity to the two previous Streptomyces lipase sequences was found (Sommer et al., 1997) which suggested high variability in lipases than expected for the genus Streptomyces. Generally as we well known, production of high quantity of lipase enzyme need inducers like triacylglycerols, surfactants, vegetable oils, oil industrial wastes or their hydrolysis products in the culture medium. Inducers as Tween 80 , oils of soybean and olive have been evaluated as inducers for lipase production ( $\mathrm{Li}$ et al., 2004). Due to the many applications, the availability of lipases with specific characters is needed, thus search for new lipase with different characters is important research topic. The aim of this study was isolation, purification and characterization of new lipase enzyme from the Bacillus.

Collection of samples

\section{Material and methods}

Soil samples were collected from oil - contaminated places. About 22 soil samples were obtained from 22 oil stations, Jeddah, Saudi Arabia. All soil samples were collected in sterile plastic bags

Isolation of bacteria from different oil stations

Contaminated soil samples were used for bacterial isolation on Nutrient agar medium using serial dilution method. One gram of the soil sample was suspended in $9.0 \mathrm{ml}$ of sterile distilled water and $0.1 \mathrm{ml}$ of this suspension was spread on each Petri dishes plate containing Nutrient agar medium and all plates were incubated 
at $37^{\circ} \mathrm{C}$ for 2 days. The obtained bacteria were purified by streaking and sub culturing on nutrient agar until pure cultures were obtained, then transferred to slants of the same medium and preserved at $4^{\circ} \mathrm{C}$.

\section{Rapid Screening of Lipase Producing Bacteria on Agar Plate}

The bacterial isolates were screened on Tween- Yeast extract agar medium (Kumar et al, 2012) at $37^{\circ} \mathrm{C}$ for 2 days and colonies with clear zone due to oil hydrolysis were recognized and the surrounding clear zone and colony diameters were determined after 2 days of incubation at $37^{\circ} \mathrm{C}$. The active isolates were selected and transferred to nutrient agar slants to be stored at $4{ }^{\circ} \mathrm{C}$ until used. Further screening was applied by growing the isolates in $250 \mathrm{ml}$ Erlenmeyer flask containing fermentation medium (Olive oil broth) and the enzyme activity was calculated. Olive oil broth was composed of (\%w/v): pepton $0.2 ; \mathrm{NH}_{4} \mathrm{H}_{2} \mathrm{PO}_{4} 0.1 ; \mathrm{NaCl} 0.25 ; \mathrm{MgSO}_{4} 7 \mathrm{H}_{2} \mathrm{O}$ 0.04; $\mathrm{CaCl}_{2} .2 \mathrm{H}_{2} \mathrm{O}$ 0.04; olive oil $2.0(\mathrm{v} / \mathrm{v}) ; \mathrm{pH} 7.0 ; 1 \mathrm{ml}$ of Tween 80 as emulsifier (Mobarak-Qamsari et al., 2011).

\section{Identification of the selected bacterium to genus level}

The selected isolate was identified to genus level using morphological and physiological tests (Nonomura, 1974) according to Bergey's Manual of systematic Bacteriology (Holt et al., 1994). Further, the forward primer 5'-AGTTTGATCATGGTCAG-3' and the reverse primer5'-GGTTACCTTGTTACGACT-3' were used to amplify the $16 \mathrm{~S}$ rDNA gene and the DNA sequence was compared to the GenBank database the BLAST program.

\section{Preculture preparation and bacterial growth}

Preculture were used to study the effects of some factors on lipase production. About $2 \mathrm{ml}$ of bacteria suspension of the selected HM10 $\left(4 \times 10^{6} \mathrm{CFU} / \mathrm{ml}\right)$ was transferred to Nutrient broth $(50 \mathrm{ml})$ and incubated in shaker incubation at $37^{\circ} \mathrm{Cfor} 48 \mathrm{hr}$. Then, each $2 \mathrm{ml}$ of the preculture was used to inoculate $50 \mathrm{ml}$ of the Olive oil medium. Bacterial growth was detected by measuring the optical density at $550 \mathrm{~nm}$ using spectrophotometer (UV-1650PC, SHIMADZD). All experiments were carried out in triplicate and averages were calculated.

\section{Enzyme Assays}

Lipase activity was measured by titrimetric method using olive oil, emulsified with gum Arabic, as a substrate (Sirisha et al., 2010). The liberated fatty acids was neutralized after titration using $0.05 \mathrm{M} \mathrm{NaOH}$ and phenophathelin indicator

\section{Selection of the best lipase producer isolate:}

From the screening test, 3 bacterial isolates showed the maximum production of lipase, thus they were selected to be grown in the $250 \mathrm{ml}$ Erlenmeyer flasks containing $50 \mathrm{ml}$ of the sterile olive oil medium. Each flask was inoculated by $2 \mathrm{ml}$ of the preculture $\left(4 \times 10^{6} \mathrm{CFU} / \mathrm{ml}\right)$. The flasks were incubated at $37^{\circ} \mathrm{C}$ for 2 days with agitation at $120 \mathrm{rpm}$. At the end of the incubation period, the growth and lipase were determined. The bacterial isolate, which showed maximum lipase production, was selected for more studies.

\section{Factors affecting on Lipase production by the selected isolate}

Four different broth media (Medium 1, 2, 3 and 4) were used to test the ability of the active of isolate HM10 to produce lipase. The tested media were Tween- Yeast extract (Kumar et al, 2012), Tween - peptone (Modified Kumar et al, 2012), Olive oil- Yeast extract (Sirisha et al, 2010) and Olive oil - dextrose (Aly et al., 2012) in addition to Olive oil medium which was used as control. Fifty ml of these different media were dispensed in $250 \mathrm{ml}$ flasks. After sterilization, the flasks were inoculated with $2 \mathrm{ml}$ of precultures $\left(4 \times 10^{6}\right.$ $\mathrm{CFU} / \mathrm{ml})$ and incubated using shaking incubator $\left(120 \mathrm{rpm}\right.$ and $37^{\circ} \mathrm{C}$ for 2 days $)$. The cells were collected and the filtrate was used to measure lipase production as mention before. Similarly, the effect of different initial $\mathrm{pH}$ values, incubation temperature, and incubation period on lipase production was determined as described in Aly et al., (2012). Moreover, effect of different carbon and nitrogen sources was also evaluated.

\section{Lipase production and purification}

About $3000 \mathrm{ml}$ of production medium at $\mathrm{pH} 7$ were distributed in $250 \mathrm{ml}$ flasks, each flask containing $50 \mathrm{ml}$. Each flask was inoculated with $2 \mathrm{ml}$ of $4 \times 10^{6} \mathrm{CFU} / \mathrm{ml}$ of the preculture and the flasks were incubated at $37^{\circ} \mathrm{C}$ and $120 \mathrm{rpm}$ for 2 days. At the end of incubation period, the enzyme was extracted from the filtrate, precipitated by using $80 \%$ of ammonium sulphate at $4^{\circ} \mathrm{C}$, purified using Sephadex G100 column chromatography and sodium dodecyl sulphate polyacrylamid gel electrophoresis (SDS-PAGE) according to Lammli (1970) was used to determined its molecular weight. 


\section{Factors affecting enzyme activity}

The effect of incubation temperature, $0,30,40,45,50,55$ and $60^{\circ} \mathrm{C}$ and different $\mathrm{pH}, 3,4,5,7,8$ and 9 was determined in the reaction mixture containing $300 \mu \mathrm{l}$ of enzyme $300 \mu \mathrm{l}$ of a substrate. The after $15 \mathrm{~min}$., the reaction was stopped and fatty acids were extracted by addition of $1.0 \mathrm{ml}$ of acetone: ethanol solution $(1: 1, \mathrm{v} / \mathrm{v})$. The amount of fatty acids was titrating using phenophathelin indicator. Similarly, effect of enzyme concentrations and different metal ions (10mM) like $\mathrm{KCl}, \mathrm{NaH}_{2} \mathrm{PO}_{4} \cdot 2 \mathrm{H}_{2} \mathrm{O}, \mathrm{FeSO}_{4} .7 \mathrm{H}_{2} \mathrm{O}, \mathrm{CaCl}_{2} \cdot 2 \mathrm{H}_{2} \mathrm{O}$ and $\mathrm{MgSO}_{4} .7 \mathrm{H}_{2} \mathrm{O}$ were investigated

\section{Statistical analysis}

Statistical analyses were performed using the statistical Package for Social Science (SPSS for windows, version 16) (SPSS Inc., Chicago, IL, USA). All values were expressed as mean \pm standard deviation (Mean \pm SD) and using t-test, difference between samples considered significant at $\mathrm{P}>0.05$.

\section{Results}

Soil samples were dried and serially diluted in sterile dist water and used for bacterial isolation. About 22 bacterial isolates were obtained on Nutrient Agar (NA) medium. All the bacterial isolates were screened on Tween- Yeast extract agar medium containing Tween as a carbon source $(10 \mathrm{~g} / \mathrm{L})$ and the diameter of clear zones $(\mathrm{mm})$ were determined for each plate. The diameter of the clear zone was ranged from 9-28 $\mathrm{mm}$ and the maximum diameter of the clear zones were 28, 25 and $20 \mathrm{~mm}$ for the isolate HM10, HM15 and HM20, respectively (Table, 1). The three active isolates (HM10, HM15, HM20) were grown in liquid Olive oil medium, growth and enzyme activity were determined after $48 \mathrm{hr}$ in culture filtrate. Enzyme production was measured as $\mathrm{U} / \mathrm{ml}$, one unit is the amount of enzyme releasing one $\mu \mathrm{mol}$ of lipid per minute under the ideal conditions. Table 1 and Figure 1 showed that, among the three examined bacterial isolates, the extracellular enzyme of the isolate HM10 which was isolated from oil contaminated soil produced quantitatively high lipase as measured using olive oil as substrate $(4.5 \mathrm{U} / \mathrm{ml})$. The minimum extracellular enzyme production was achieved by the isolate HM15 $(2.8 \mathrm{U} / \mathrm{ml})$. Similarly, the production of extracellular lipase achieved by the isolate HM15 was moderate $(3.6 \mathrm{U} / \mathrm{ml})$. According to the previous results, the isolate HM10 was selected for more detail studies in lipase production.

\section{Identification of the selected bacterial Isolate HM10}

Physiological and biochemical characteristics were determined for the selected bacterial isolate HM10 by the procedures outlined in Manual of Methods for General Bacteriology. Cell morphology, Gram stain, spore formation, some enzyme production, degradation of some material and resistance to antibiotics were determined. The 16S rRNA sequences and phylogenetic tree analysis were determined as described by Rainey $e t$ al. (1993).

Colonies of the selected bacterial isolate HM10 appeared on NA within $48 \mathrm{hrs}$ at $37^{\circ} \mathrm{C}$ and reached a diameter of 10 to $20 \mathrm{~mm}$ after one week. The colonies had cream colored, changed to dark yellowish white by aging. They were smooth, glistening, opaque, low convex, with an entire edge. Colonies were creamy, smooth, and opaque, with slightly irregular edges on Olive oil containing medium and reached a diameter of 15 to 19 $\mathrm{mm}$ in 5 days. Young cells were Gram positive motile bacilli measuring 1.5-3 $\mu \mathrm{m}$. Negative results were obtained for methyl red test, gelatin liquefaction, hydrolysis of Tween 80, egg yolk lecithinase, hemolysis and esculin while positive for Voges-Proskauer test, indole and urease production, hemolysis and utilization of casein, cellulose, and starch hydrolysis. The isolate was aerobic, tolerant to $\mathrm{NaCl}$ up to $5 \%$ and the growth was $30-37^{\circ} \mathrm{C}$ and $\mathrm{pH} 5-8$. Using Muller-Hinton agar, the isolate was sensitive to chloramphenicol and tetracycline and was resistant to novobiocin and erythromycin.

DNA was extracted and the entire 16S rRNA sequence was determined and was compared to the GenBank database in the National Center for Biotechnology Information (http://www.ncbi.nlm.nih.gov) using the BLASTN 2.2.6 and the Geneious v 5.5 programs (http://www.geneious.com). The isolate was found belonging to the Bacillus group with homology level $(95 \%)$ as depicted in the phylogenetic tree analysis (Figure 2). It was identified as Bacillus coagulans HM10.

\section{Effect of some factors on lipase production by the selected isolate HM10}

The selected isolate HM10 was grown for 2 days in several broth media such as Olive oil medium (control), medium 1, medium 2, medium 3 and medium 4. The obtained results presented in Figure 3 indicated that the best medium for lipase production was medium 4 . Thus medium 4 was selected for the coming experiments. The maximum lipase production was at $\mathrm{pH} 7.0$ and $37^{\circ} \mathrm{C}$ after 2 days of incubation (Figures 4, 5, 6). Carbon source in medium 4 was replaced with different carbon sources like palm oil, ghee, coconut oil, sunflower oil and mustard oil at concentration of $1 \%(\mathrm{w} / \mathrm{v})$. The selected isolate HM10 can utilize all the previous carbon sources and the best carbon source for enzyme production was Mustard oil, while Coconut oil 
gave the lowest enzyme production (Figure 7). The best nitrogen source for enzyme production was Yeast extract whereas Casien was the lowest one (Figure 8).

\section{Lipase purification and characterization}

The lipase enzyme was precipitated by $80 \%$ of ammonium sulphate, dialyzed and purified by sephadex G100 column chromatography. The protein was determined by measuring the absorption at $\mathrm{A}_{280}$ and the active fractions with high absorbance at $280 \mathrm{~nm}$ and lipase activities were collected, lyophilized and used for enzyme characterization and molecular weight determination. The molecular weight was determined to be $62 \mathrm{KDa}$ using gel electrophoresis (Figure 9). The optimum temperature for the purified lipase enzyme was $50^{\circ} \mathrm{C}$ and $\mathrm{pH} 7$ (Figures 10, 11). The effects of metal ions on enzyme activity (e.g., $\mathrm{KCl}, \mathrm{NaH}_{2} \mathrm{PO} 4.2 \mathrm{H}_{2} \mathrm{O}, \mathrm{CaCl}_{2} .2 \mathrm{H}_{2} \mathrm{O}$, $\mathrm{MgSO}_{4} .7 \mathrm{H}_{2} \mathrm{O}$ and $\mathrm{FeSO}_{4} .7 \mathrm{H}_{2} \mathrm{O}(10 \mathrm{mM})$ were investigated by adding them $(10 \mathrm{mM})$ to the reaction mixture. Table 2 indicated that metal ions exhibited three different effects on the enzyme activity, $\mathrm{KCl}$ and $\mathrm{CaCl}_{2} \cdot 2 \mathrm{H}_{2} \mathrm{O}$ significantly enhanced the enzyme activity; $\mathrm{MgSO}_{4} \cdot 7 \mathrm{H}_{2} \mathrm{O}$ had no obvious effects, while $\mathrm{FeSO}_{4} \cdot 7 \mathrm{H}_{2} \mathrm{O}$ and $\mathrm{NaH}_{2} \mathrm{PO}_{4} \cdot 2 \mathrm{H}_{2} \mathrm{O}$ significantly inhibited the enzyme activity.

\section{Discussion}

Lipases are a class of enzymes, which catalyze the hydrolysis of long chain triglycerides and with the rapid development of enzyme technology, bacterial lipases received much attention. Recently, the interest in lipase production was increased because of its wide range of industrial applications (Shaini and Jayasree, 2016), in food processing, detergents synthesis, wastewater treatment, diagnostic methods and cosmetics and pharmaceutical, leather preparations (Sarkar et al., 1998; Cardenas et al., 2001; Elibol and Ozer, 2001; Kamini et al., (2000). The present study explains the production and optimization of a novel lipase produced by Bacillus isolated from oil-contaminated soil collected from Saudi Arabia.

About 22 bacterial isolates (100\%) of the isolated bacteria produce lipase in their solid growth medium containing Tween as carbon source. Chaturvedi et al., (2010 a,b) reported that used selective medium containing lipids for lipase detection in Bacillus subtilis. Similarly, lipolytic activity of 34 bacterial isolates was detected using olive oil as sole carbon source ( Aly et al., 2012). On contrast, Wu and Tsai (2004) studied the hydrolysis rate of tributyrin with crude lipase from Pseudomonas fluorescenes where they reported the use of Tributyrin in lipase assay. In liquid medium, the quantities of lipase production by the 22 bacterial isolates were ranged from 0.95-1.5 U/ml. Gowland et al, (1987) reported that Bacillus sp. produced the maximum level of lipase (about $4 \mathrm{U} / \mathrm{ml}$ ) in a medium containing Tween-80 (polyoxyethylene sorbitan monooleate). Lipids material in the culture medium is essential for high lipase yield (Rathi et al., 2002, Zarevocka, 2015). Thus, lipase is inducible enzyme and need a lipid substance to be induced. The most lipase producer isolate HM10, which was obtained oil contaminated soil, was belonging to genus Bacillus and it was identified as Bacillus coagulans HM10 and the results was confirmed using 16S rDNA (Tamaoko et al., 2001; Weisburg et al., 1991). Similarly, Abdul Hamid et al. (2003) reported a lipolytic activity $(4.58 \mathrm{U} / \mathrm{ml})$ for an isolate belonging to genus Bacillus. In Malaysia, similar lipase producer bacteria, Ralstonia paucula, Bacillus subtilis, Bacillus thermoglucosidasius, Bacillus stearothermophilus and Bacillus coagulans were obtained by Abdul Hamid et al. (2003). Pseudomonas sp. and Pseudomonas aeruginosa were highly lipase producers (Haba et al., 2000) and potent lipase production from Streptomyces griseus was determined by using olive oil, palm oil and sunflower oil (Vishnupriya et al., 2010). However, the measured amounts of lipase were generally lower than for the fungi and other bacteria, like Geotricum which showed maximum lipase production $(146 \mathrm{U} / \mathrm{ml})$ when urea was used as nitrogen source (Ginalska et al., 2007).

Temperature, $\mathrm{pH}$, incubation period, carbon and nitrogen sources in addition to presence of inducer and its concentration are factors affecting lipase production (Elibol and Ozer, 2001, Immanuel et al., 2008). In the present study, maximum lipase production by the selected bacterium HM10 was obtained in medium 4 which contained olive oil and Tween 80 as a source of lipid. Rowe and Gilmour (1982) and Hasan et al. (2006) used Tween 20 or 80 to enhance secretion of lipase. Emanuilova et al., 1993, Handelsman and Shoham, 1994and noticed that Tween 80 is the best inducer for lipase production while Espinosa et al. (1990) suggested that Tween can be used as an excellent inducers due to chemical similarities to natural oils and as a surfactant, stimulating the enzyme release. Lipase production was enhanced in Bacillus stearothermophilus (Gowland et al., 1987), Bacillus sp. (Sidhu et al., 1998), Rhizopus delemar (Espinosa et al., 1990), Candida rugosa (Song et al., 2001) by using Tween 80 .

The factors affecting lipase production were studied in shake-flask culture and the best conditions were applied for maximum production of the enzyme. Growth of the tested bacterium in medium 4 at initial $\mathrm{pH} 7.0$ for 2 days at $37^{\circ} \mathrm{C}$ led maximum lipase production. The best medium observed by Handelsman and Shoham (1994) for lipase production from Bacillus sp. contained casamino acids and 1\% Tween 80. Hendersonula toruloidea produced lipase using $0.1 \%$ olive oil at $\mathrm{pH}$ of 6.0 while lipase production was after $120 \mathrm{hr}$. In this study, maximum lipase was found in 2 days at $37^{\circ} \mathrm{C}$ and $\mathrm{pH} 7.0$. Bacterial lipases production needed adequate 
carbon source and sufficient incubation period which varied from a few hours to several days depending on the bacteria and environmental conditions (Vishnupriya et al., 2010). Similarly, the lipase from G. candidum (Baillargeon et al., 1989) showed the highest activity when the initial $\mathrm{pH}$ of the medium was adjusted to $\mathrm{pH} 7.0$ while $\mathrm{pH}$ was 5.0 for Geotrichum (Macedo et al, 1997), 6.0 for Geotrichum-like R59 (Ginalska et al., 2007). The molecular weight of the purified lipase has $62 \mathrm{kDa}$ and the same molecular weight was obtained by Abdul Hamid et al. (2003). The maximum enzyme activity was at $50^{\circ} \mathrm{C}$ and $\mathrm{pH} 7.0$ and presence of $\mathrm{K}^{+}$and $\mathrm{Ca}^{++}$ions enhance enzyme activity. Similar results were obtained for Streptomyces lipase (Aly et al., 2012). Other studies are needed for obtaining the interesting characters of lipases and their applications.

\section{References}

[1]. Abdul Hamid NS, Zen HB, Tein OB, Halifah YM, Saari N (2003). Screening and identification of extracellular lipase-producing thermophilic bacteria from a Malaysian hot spring. World J. Microbiol. Biotech., 19(9): 961-968.

[2]. Abramic M, Lescic I, Korica T, Vitale L, Saenger W, Pigac J (1999). Purification and properties of extracellular lipase from Streptomyces rimosus. Enz Microb Technol 25:522- 529.

[3]. Aly M.M., Tork S., Al-Garni S and Nawar L. (2012). Production of lipase from genetically improved Streptomyces exfoliates LP10 isolated from oil- contaminated soil . African Journal of Microbiology Research Vol. 6(6), pp. 1125-1137.

[4]. Baillargeon MW, Bistline RG, Sonnet PE (1989). Evaluation of strains of Geotrichum candidurn for lipase production and fatty acid specificity. Appl. Microbiol. Biotechnol., 30, 92-96.

[5]. Borkar PS, Bodade RG, Rao SR, Khobragade CN (2009) Purification and characterization of extracellular lipase from a new strainPseudomonas aeruginosa SRT 9. Braz J Microbiol 40:358-366.

[6]. Cardenas J, Alvarez E, de Castro-Alvarez M-S, Sanchez-Montero J-M, Valmaseda M, Elson SW, Sinisterra JV. (2001). Screening and catalytic activity in organic synthesis of novel fungal and yeast lipases. J Mol Catal B: Enzym., 14:111-123.

[7]. Chaturvedi M, 1Singh M, Rishi M. C and Rahul K. (2010a).I solation of lipase producing bacteria from oil contaminated soil for the production of lipase by solid state fermentation using coconut oil cake. International Journal of Biotechnology and Biochemistry, Vol 6 (4) pp. 585-594

[8]. Chaturvedi M, Singh M, Man CR, Pandey S (2010b). Lipase Production from Bacillus subtilis MTCC 6808 by solid state fermentation using ground nut oil cakes as substrate. Res. J. Microbiol., 5: 725-730.

[9]. Cruz H, Perez C, Wellington E, Castro C, Serv L (1994). Sequence of the Streptomyces albus G lipase-encoding gene reveals the presence of a prokaryotic lipase family. Gene, 144:141-142.

[10]. Dartois, V., Baulard, A., Schanck, K. and Colson, C. (1992). Cloning, nucleotide sequence and expression in Escherichia coli of a lipase gene from Bacillus subtilis 168. Biochimica et Biophysica Acta 1131, 253-260.

[11]. Elibol M and Ozer D (2001). Influence of oxygen transfer on lipase production by Rhizopus arrhizus. Process Biochem., 36:325329.

[12]. Emanuilova E, Kambourova M, Dekosvka M, Manolov R (1993). Thermoalkalophilic lipase producing Bacillus selected by continuous cultivation. FEMS Microbiol. Lett., 108: 247-250.

[13]. Espinosa E, Sanchez S, Farres A (1990). Nutritional factors affecting lipase production by Rhizopus delemar CDBB H313. Biotechnol. Lett., $12: 209-214$.

[14]. Ginalska G, Cho H, Cho N, Bancerzl R, Kornil T, Leonowicz1 L, Shin S, Ohga S (2007). Effect of culture conditions on growth and lipase production by a newly isolated strain, Geotrichum-like R59 (Basidiomycetes). J. Fac. Agr., Kyushu Univ., 52(1): 29-34.

[15]. Ginalska G, Cho H, Cho N, Bancerzl R, Kornil T, Leonowicz1 L, Shin S, Ohga S (2007). Effect of culture conditions on growth and lipase production by a newly isolated strain, Geotrichum-like R59 (Basidiomycetes). J. Fac. Agr., Kyushu Univ., 52(1): 29-34.

[16]. Gowland, P, Kernick M. and Sundaram T. K. (1987). Thermophilic bacterial isolates producing lipase. FEMS Microbiology Letters Volume 48, Issue 3, Pages 339-343

[17]. Haba E., Bresco O., Ferrer C., Marqués A., Busquets M. and Manresa A. (2000). Isolation of lipase-secreting bacteria by deploying used frying oil as selective substrate. Enzyme and Microbial Technology Volume 26, (1) Pages 40-44.

[18]. Handelsman T and Shoham Y (1994). Production and characterization of an extracellular thermostable lipase from a thermophilic Bacillus sp. J. Gen. Appl. Microbiol., 40: 435-443.

[19]. Hasan F, Shah AA, Hameed A (2006). Industrial applications of microbial lipases. Enzyme and Microbial Technology., 39: 235251.

[20]. Holt J.G., Krieg N.R., Sneath P.H.A., Staley J.T., Williams S.T. (1994). Bergey's Manual of Determinative Bacteriology, 9th Ed. Williams \& Wilkins, Baltimore, MS, USA.

[21]. Immanuel G, Esakkiraj P, Jebadhas A, Iyapparaj P (2008). Investigation of lipase production by milk isolate Serratia rubidaea. Food Technol. Biotechnol., 46(1): 60-65.

[22]. Jaeger KE, Ransac S, Dijkstra BW, Colson C, Van Heuvel M, Misset O (1994). Bacterial lipases. FEMS Microbiol. Rev., 15: 29 63.

[23]. Kamini, N.R., Fujii T., Kurosu T and Iefuji H (2000). Production, purification and characterization of an extracellular lipase from the yeast, Cryptococcus sp. S-2. Process Biochemistry, 36:317- 324.

[24]. Kim EK, Jang WH, Ko JH, Kang JS, Noh MJ, Yoo OJ. (2001). Lipase and its modulator from Pseudomonas sp. strain KFCC 10818: proline-toglutamine substitution at position 112 induces formation of enzymatically active lipase in the absence of the modulator. J Bacteriol., 183:5937-5941.

[25]. Kumar D, Kumar L, Nagar S, Raina C, Parshad R and Gupta V K (2012). Screening, Isolation and production of lipase/esterase producing Bucillus sp. Strain DVL2 and its potential in esterification and resolution reactions. Archives of Applied Science Research, 4 (4):1763-1770.

[26]. Li C, Cheng C, Chen T (2004). Fed-batch production of lipase by Acinetobacter radioresistens using Tween 80 as carbon source. Biochem. Eng. J., 19(1): 25-31.

[27]. Macedo GA, Park YK, Pastore GM (1997). Partial purification and characterization of an extracellular lipase from a newly isolated strain of Geotrichum sp. J. Brazil. Soc Microbiol., 28: 90-95.

[28]. Maugard T., Rejasse B. and Legoy M.D (2002). Synthesis of water-soluble retinol derivatives by enzymatic method, Biotechnol. Prog., 18, 424-428.

[29]. Mobarak-Qamsari E, Kasra-Kermanshahi R , Moosavi-nejad Z (2011). Isolation and identification of a novel, lipase-producing bacterium, Pseudomnas earuginosa. Iran. J. Microbiol. 3 (2) : 92-98. 
[30]. Mobarak-Qamsari E, Kasra-Kermanshahi R, Moosavi-nejad Z (2011). Isolation and identification of a novel, lipase-producing bacterium, Pseudomnas earuginosa. IRAN. J. Microbiol, 3 (2) : 92-98

[31]. Moeller, B., Vetter, R., Wilke, D. and Foullois, B. (1992) Alkane lipases from Bacillus and the cloning of their genes. Patent number WO9116422. Applicant(s) Kali Chemie A.-G.

[32]. Pérez C, Juárez K, García-Castells E, Soberón G, Servín-González L (1993). Cloning, characterization, and expression in Streptomyces lividans 66 of an extracellular lipase-encoding gene from Streptomyces sp. M11. Gene, $123: 109$-114.

[33]. Rainey F A, Fritze D and Stackebrandt E (1993). The phylogenetic diversity of thermophilic members of the genus Bacillus, as revealed by 16 s rDNA analysis. FEMS Microbiol Lett 115,205-212.

[34]. Ramchuran SO, Vargas VA, Hatti-Kaul R, Karlsson EN (2006). Production of a lipolytic enzyme originating from Bacillus halodurans LBB2 in the methylotrophic yeast Pichia pastoris. Appl. Microbiol. Biotechnol., 71: 463-472.

[35]. Rathi, P., Goswami, V.K., Sahai, V. and Gupta, R. (2002) Stastical medium optimization and production of a thermostable lipase from Burkholderia cepapcia in a bioreactor. Journal of Applied Microbiology, 93: 930-945.

[36]. Riaz, A., A. Younis, M. Hameed and S. Kiran (2010). Morphological and biochemical responses of turf grasses to water deficit condition. Pak. J. Bot., 42(5): 3441-3448.

[37]. Rowe MT, Gilmour A (1982). Growth, enzyme production and changes in oxygen tension occurring during batch cultivation of psychrotrophic Pseudomonas fluorescence strains. Milchwissenschaft, 37: 597-600.

[38]. Sangeetha, R., I. Arulpandi and A. Geetha (2011). Bacterial lipases as potential industrial biocatalysts: An overview. Res. J. Microbiol., 6: 1-24.

[39]. Sarkar S., Sreekanth B., Kant S., Banerjee R and Bhattacharyya B.C. (1998). Production and optimization of microbial lipase. Biopro. Eng., 19: 29-32.

[40]. Shaini, V.P., and Jayasree, S. (2016). Isolation and characterization of lipase producing bacteria from windrow compost. Int.J.Curr.Microbiol.App.Sci. 5(5): 926-933.

[41]. Shaini, V.P., and Jayasree, S. (2016). Isolation and characterization of lipase producing bacteria from windrow compost. Int.J.Curr.Microbiol.App.Sci. 5(5): 926-933.

[42]. Sidhu P, Sharma R, Soni SK, Gupta JK (1998). Production of extracellular alkaline lipase by a new thermophillic Bacillus sp. Folia Microbiol., 43(1): 51-54.

[43]. Sirisha E, Rajasekar N and Narasu ML (2010). Isolation and optimization of lipase producing bacteria from oil contaminated soils. Advances in Biological Research, 4(5):249-252.

[44]. Sommer P, Bormann C, Godz F (1997). Genetic and biochemical characterization of a new extracellular lipase from Streptomyces cinnamomeus. Appl Environ Microbiol., 63:3553-60

[45]. Song QX, Lin JP, Rong YP, Wei DZ (2001). Studies on lipase production from Candida rugosa. Chin. J. Biotechnol., $171: 101-104$.

[46]. Takamoto T, Shirasaka H, Uyama H, Kobayashi S. (2001). Lipase-catalyzed hydrolytic degradation of polyurethane in organic solvent. Chem Lett., 6:492-3.

[47]. Vishnupriya B, Sundaramoorthi C, Kalaivani M, Selvam K (2010). Production of lipase from Streptomyces griseus and evaluation of Bioparameters. International J. Chem. Tech. Res., 2(3): 1380-1383.

[48]. Wei YY, Swenson L, Castro C, Derewenda U, Minor W, Arai H, Aoki J, Inoue K, Servín-González L and Derewenda ZS (1998). Structure of a microbial homologue of mammalian platelet-activating factor acetylhydrolases: Streptomyces exfoliatus lipase. Angström Resolut. Struct., 6: 511-519.

[49]. Weisberg W.G., Barns S.M., Pelletier D.A., Lane D.J. (1991). 16S Ribosomal DNA amplification for Phylogenetic Study. J. bacteriol., 173(2): 697-703.

[50]. Zarevocka M. (2015). Olive Oil as Inductor of Microbial Lipase. www.intechopen.com

Table 1. Lipase production by the selected isolates grown in olive oil agar and broth medium

\begin{tabular}{|c|c|c|c|c|c|c|}
\hline \multirow[t]{2}{*}{ Organism used } & \multirow{2}{*}{$\begin{array}{l}\text { Gram } \\
\text { reaction }\end{array}$} & \multicolumn{2}{|c|}{$\begin{array}{l}\text { Lipase production on solid } \\
\text { agar medium }\end{array}$} & \multicolumn{3}{|c|}{ Lipase production in liquid medium } \\
\hline & & Growth & $\begin{array}{c}\text { (Clear } \\
\text { zone, } \mathbf{m m})\end{array}$ & $\begin{array}{l}\text { Growth } \\
\mathbf{A}_{550} \mathrm{~nm}\end{array}$ & Used vol. of $\mathrm{NaOH}$ & $\mathrm{U} / \mathrm{ml}$ \\
\hline HM10 & $+\mathrm{ve}$ & +++ & 28 & 1.50 & 1.40 & 4.50 \\
\hline HM15 & $+\mathrm{ve}$ & +++ & 25 & 0.95 & 0.915 & 2.85 \\
\hline HM20 & -ve & ++ & 20 & 1.20 & 1. 21 & 3.60 \\
\hline
\end{tabular}

++++ :Excellent growth $(3-4 \mathrm{~cm}),+++$ : Moderate growth $(2.9-2 \mathrm{~cm}), \quad$ +ve: Positive reaction, -ve: Negative reaction

Table 2. Effect of different metal ions on enzyme activity produced by the selected isolate HM10

\begin{tabular}{|c|c|c|}
\hline Metal ions & Concentration & Relative enzyme activity \\
\hline $\mathrm{KCl}$ & $10 \mathrm{mM}$ & $123^{*}$ \\
\hline $\mathrm{FeSO}_{4} \cdot 7 \mathrm{H}_{2} \mathrm{O}$ & $10 \mathrm{mM}$ & $89^{*}$ \\
\hline $\mathrm{CaCl}_{2} \cdot 2 \mathrm{H}_{2} \mathrm{O}$ & $10 \mathrm{mM}$ & $140^{*}$ \\
\hline $\mathrm{MgSO}_{4} \cdot 7 \mathrm{H}_{2} \mathrm{O}$ & $10 \mathrm{mM}$ & 103 \\
\hline $\mathrm{NaH}_{2} \mathrm{PO}_{4} \cdot 2 \mathrm{H}_{2} \mathrm{O}$ & $10 \mathrm{mM}$ & $88^{*}$ \\
\hline $\mathrm{Control}$ & 0.0 & 100 \\
\hline
\end{tabular}

*: significant results at $\mathrm{p} \leq 0.05$ 


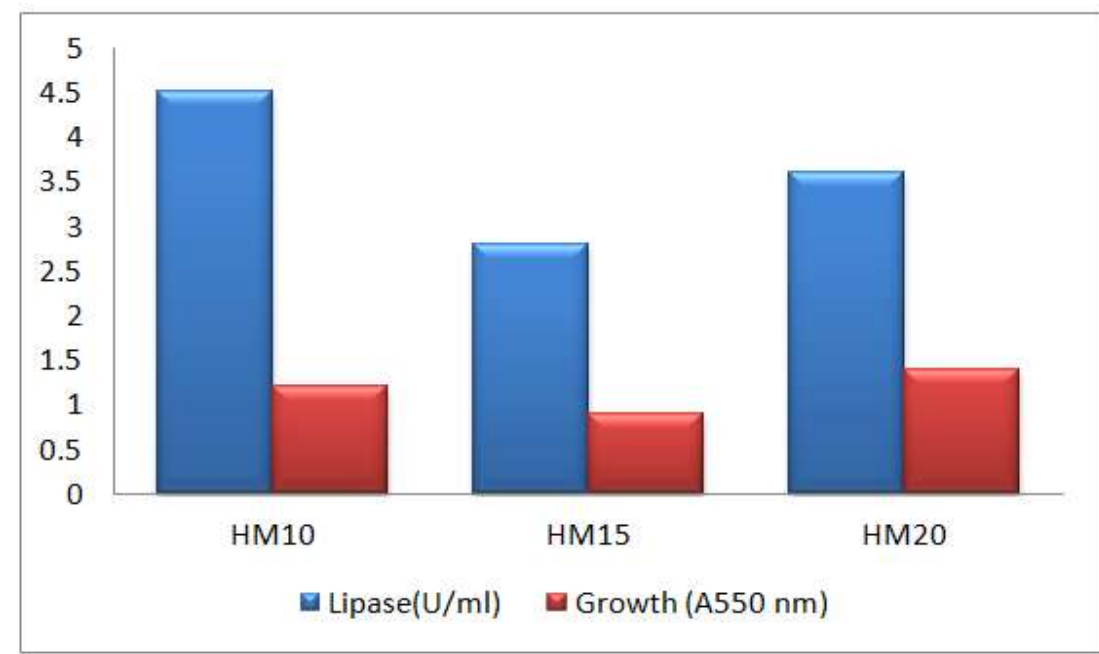

Figure 1. Growth and Lipase production of the selected isolates grown in Olive oil broth medium

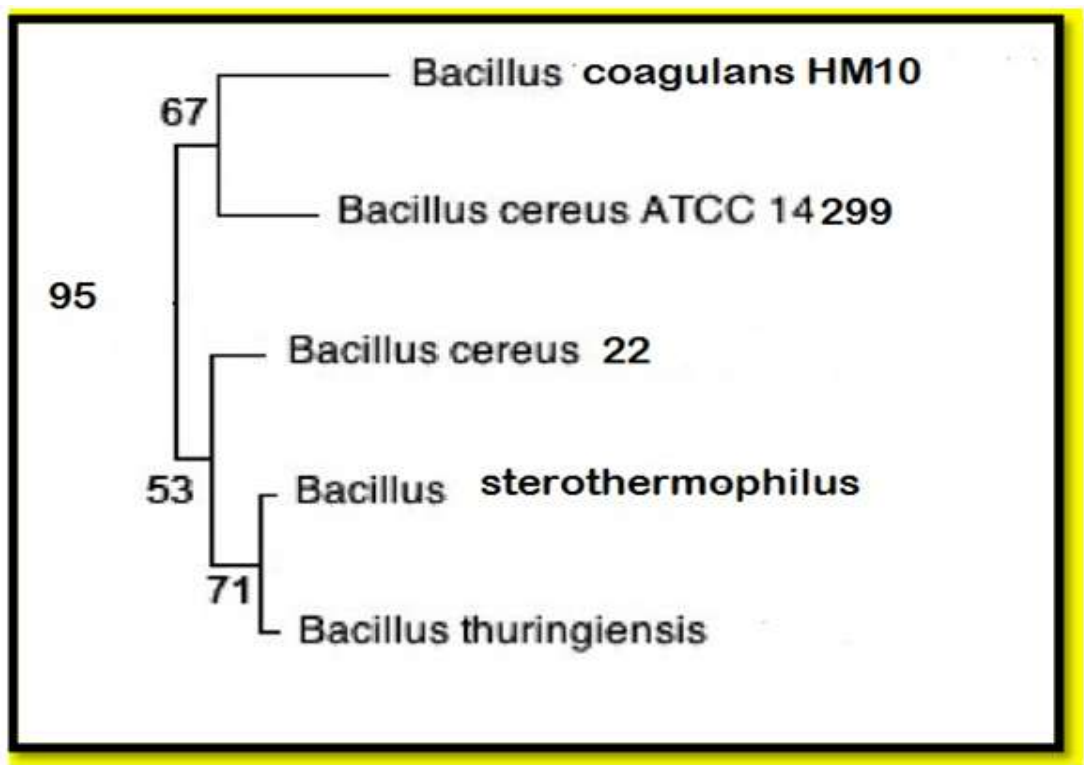

Figure 2. The phylogenetic tree of the isolate HM0 and the most related isolates

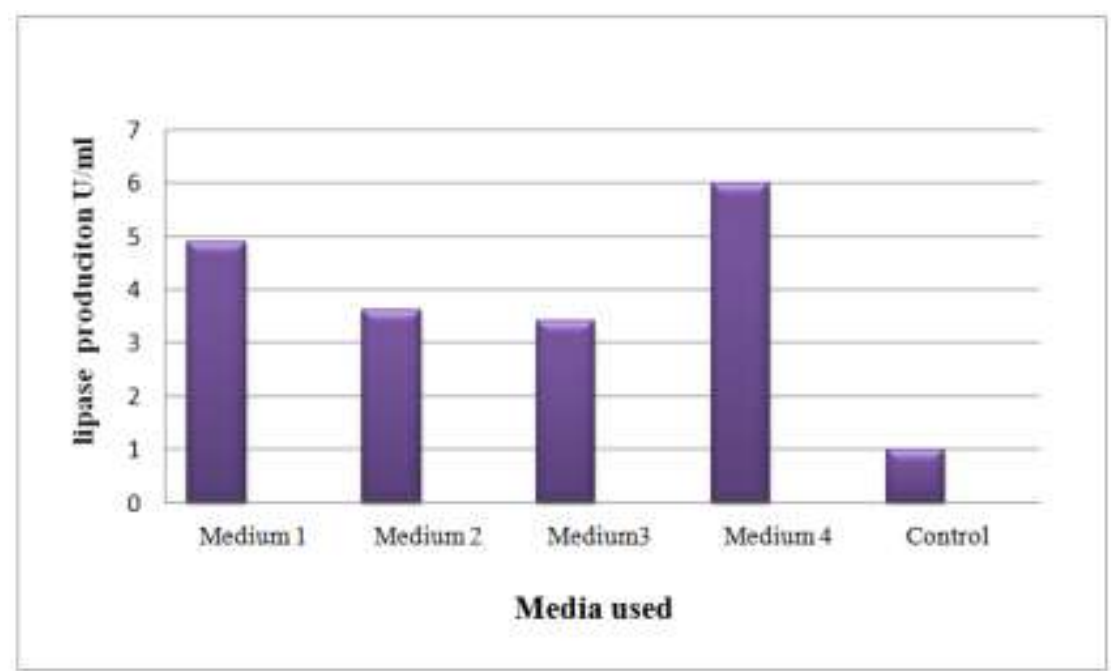

Medium1: Tween- Yeast extract, Medium 2: Tween - peptone, Medium 3: Olive oil- Yeast extract, Medium 4: Olive oil - dextrose, Control: Olive oil

Figure 3. Lipase productions by the selected isolate in different media 


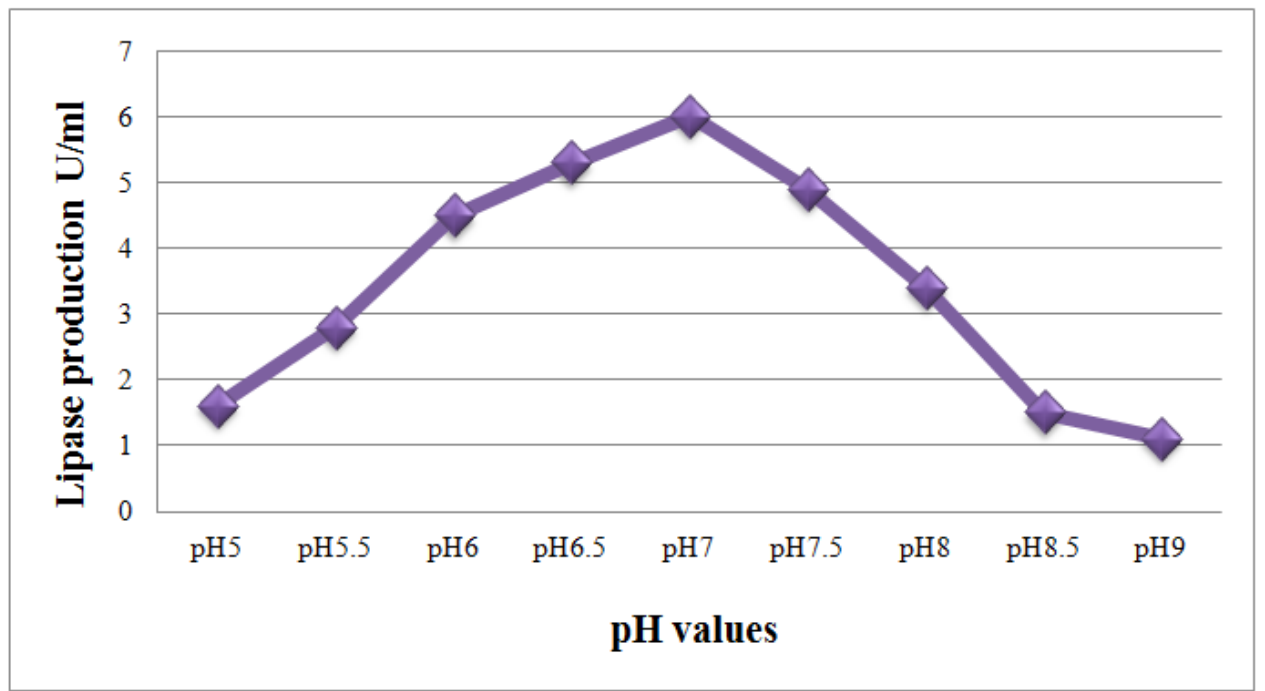

Figure 4. Effect of different $\mathrm{pH}$ values on lipase production produced by the selected isolate HM10

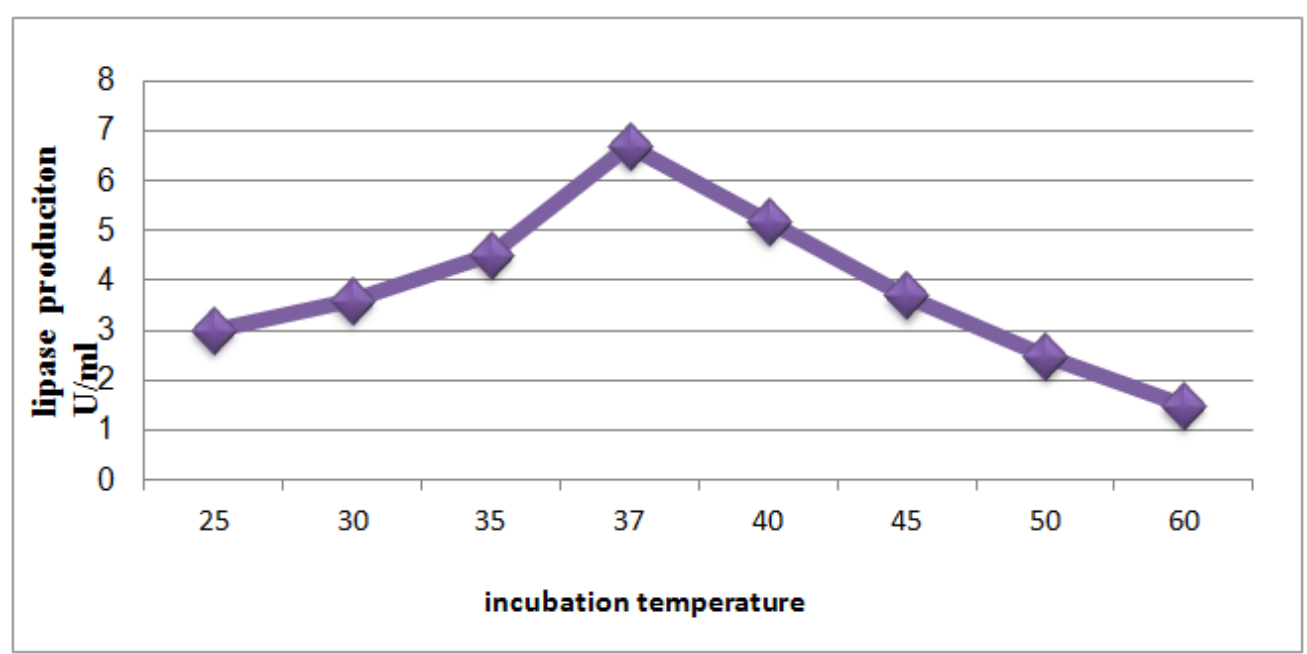

Figure 5. Effect of different incubation temperature on the lipase production by the selected isolate HM10

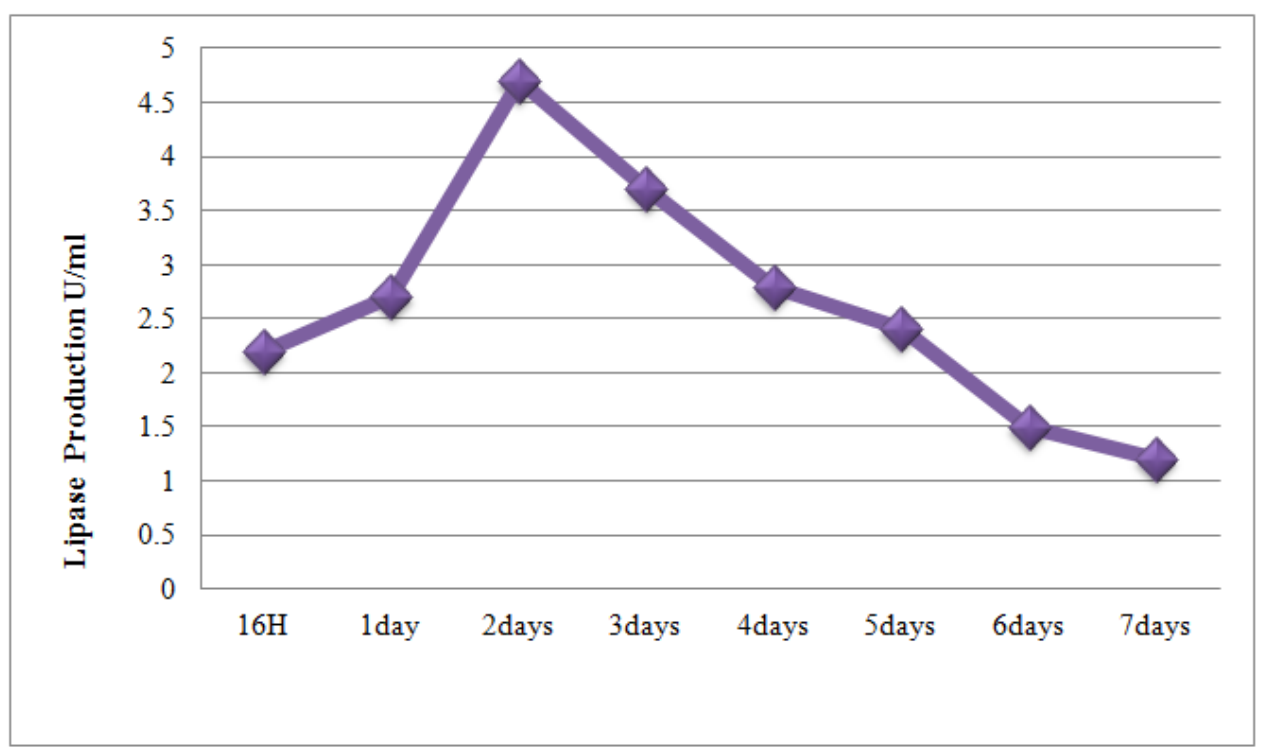

Figure 6. Effect of different incubation period on lipase production produced by the selected isolate HM10 


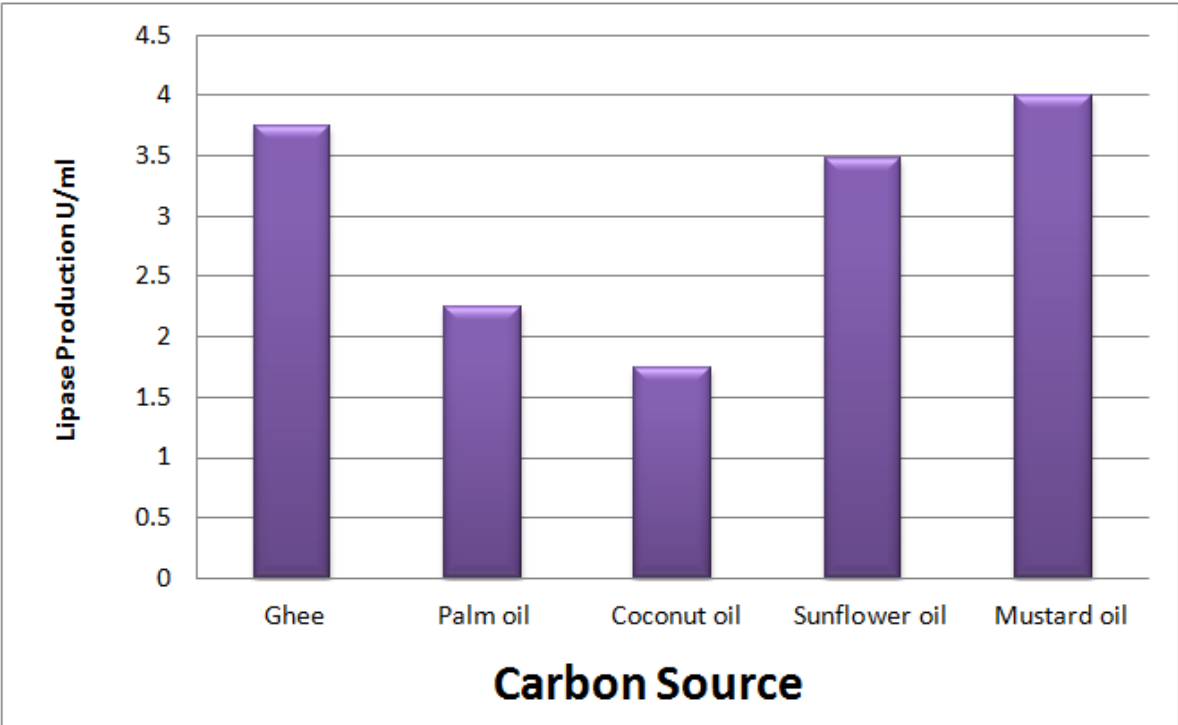

Figure 7. Effect of different carbon source on the lipase production by the selected isolate HM10

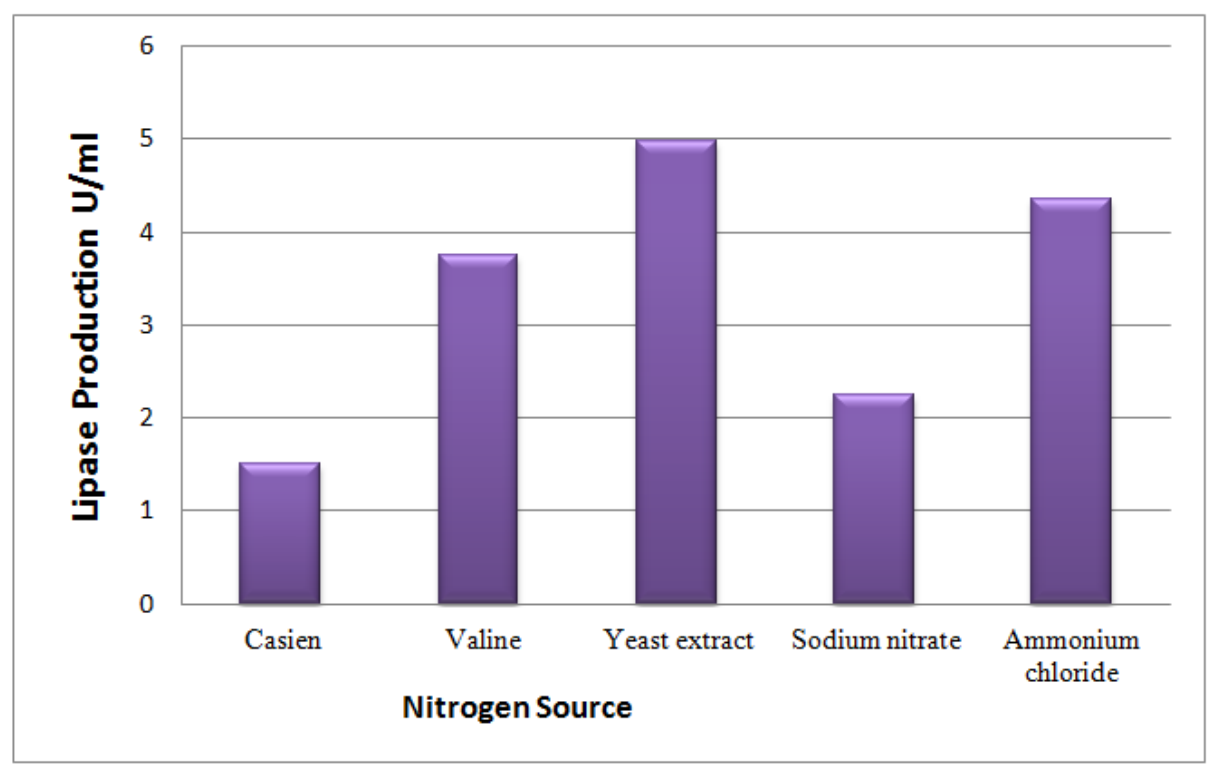

Figure 8. Effect of different nitrogen source on the lipase production by the selected isolate HM10

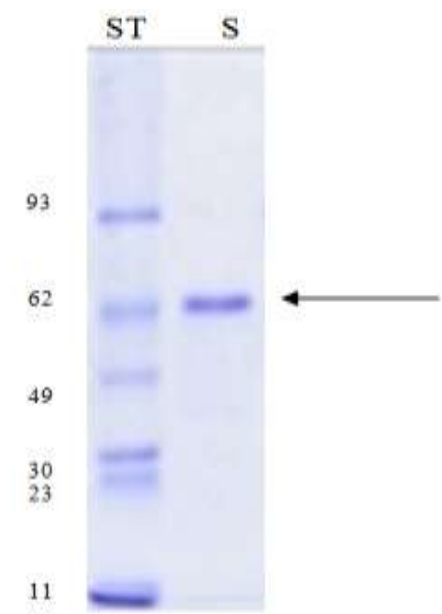

Figure 9. SDS-PAGE profile of purified lipase. Lane 1: standard protein marker (ST), lane 2: purified lipase (S). 
Spore forming bacterium from oil contaminated soil as a source of a lipase enzyme with exogeneous ..

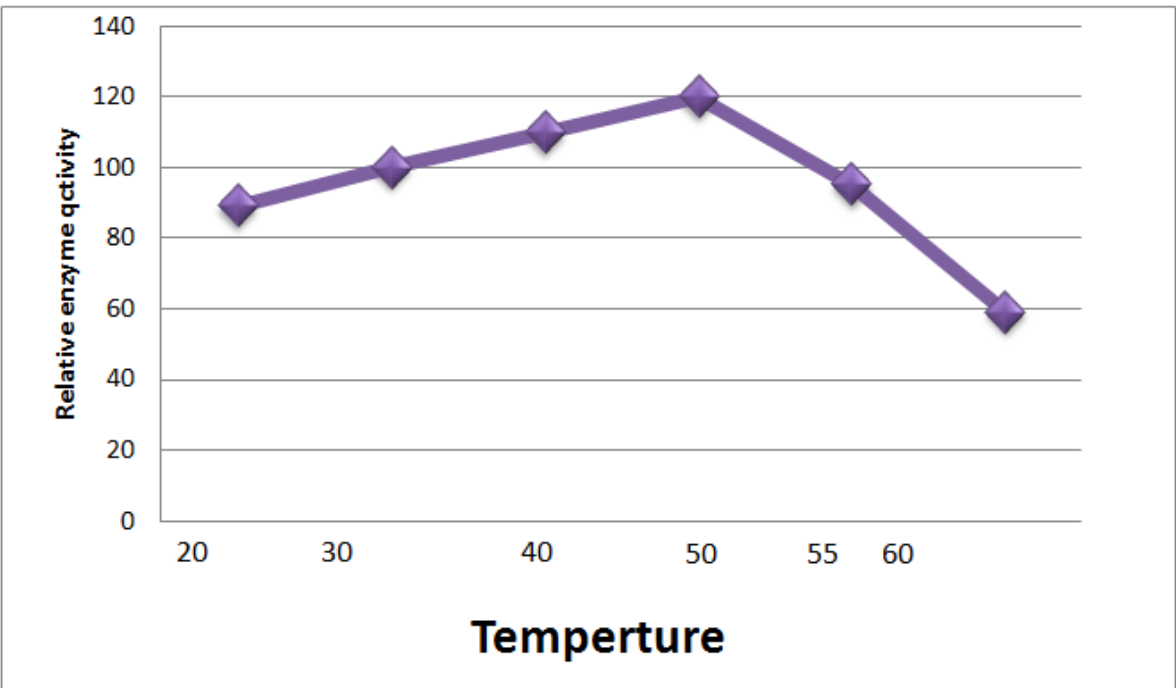

Figure 10. Effect of different incubation temperature on the enzyme activity by the selected isolate HM10

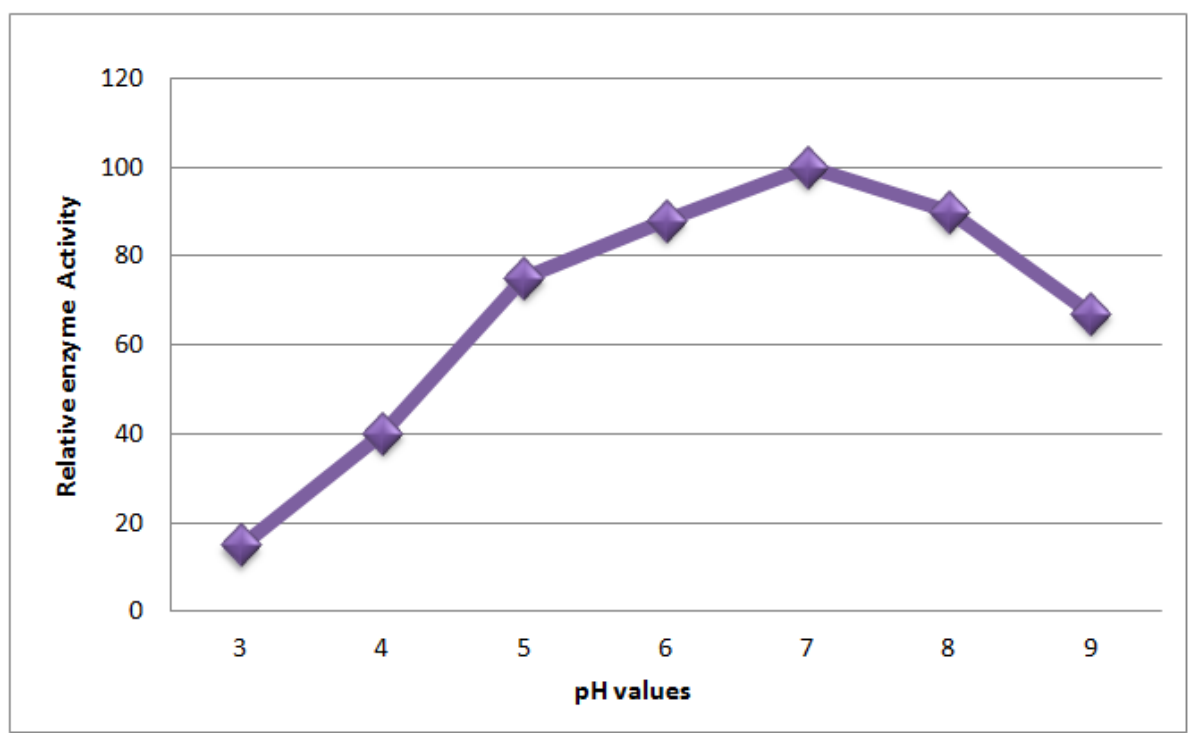

Figure 11. Effect of different $\mathrm{pH}$ values on enzyme activity produced by the selected isolate HM10 